\title{
Practical Perspectives for Management of Thyroid Nodules with Atypical Needle Biopsy
}

\author{
*Chantal A Lewis, Deepa Philip and Sushela S Chaidarun \\ Department of Endocrinology, Geisel School of Medicine at Dartmouth, Dartmouth Hitchcock Medical Center, USA
}

Submission: February 22, 2017; Published: March 01, 2017

*Corresponding author: Chantal Lewis, Department of Medicine, Section of Endocrinology, Geisel School of Medicine at Dartmouth, Dartmouth Hitchcock Medical Center, 1 Medical Center Drive, Suite 5-C, Lebanon, NH 03756, USA, Email: Chantal.A.Lewis@hitchcock.org

\begin{abstract}
The purpose of this mini-review is to review the current recommendations in the management of atypia of undetermined significance or follicular lesion of undetermined significance (AUS or FLUS). We will discuss the role of clinical and ultrasound which can be used to decide if a timely or aggressive intervention is necessary or not. Furthermore, we will address the clinical practice guidelines and determination of the course of action after initial FNA shows atypia. Lastly, the new approach of using molecular markers to help rule-out/rule-in malignancy will be addressed.

Keywords: Atypia of undetermined significance (AUS); follicular lesion of undetermined significance (FLUS); intermediate cytology; fine needle aspiration; thyroid nodule; thyroid cancer; thyroid ultrasound; molecular genetic tests; practice guidelines

Abbreviations: AACE: Association of American Clinical Endocrinologists; ATA: American Thyroid Association; AUS: Atypia of Undetermined Significance; BTA: British Thyroid Association; FLUS: Follicular Lesion of Undetermined Significance; FNA: Fine Needle Aspiration; NPV: Negative Predictive Value; PPV: Positive Predictive Value
\end{abstract}

\section{Introduction}

Over the past 40 years the incidence of thyroid cancer has nearly tripled, from 4.9 to 14.3 per 100,000 individuals, however the mortality rate has remained unchanged (approximately 0.5 deaths per 100,000) [1]. FNA is the most accurate, cost-effective and commonly used method for evaluating thyroid nodules [2]. The Bethesda system for reporting thyroid cytopathyology

2009 provides the following diagnostic categories to classify thyroid nodule cytology [3]. Diagnostic categories includes nondiagnostic or unsatisfactory, atypia of undetermined significance or follicular lesion of undetermined significance (AUS/FLUS), follicular neoplasm or suspicious for a follicular neoplasm (FN/ SFN), suspicious for malignancy, and malignant.

Table 1: The AUS interpretation as outlined by the Bethesda System for Reporting Thyroid Cytopathology. Given the diversity in this category only the most common ones are listed.

Prominent population of microfollicles that does not otherwise fulfill the criteria for

"follicular neoplasm/suspicious for follicular neoplasm."
Predominance of Hürthle cells in a sparsely cellular aspirate with scant colloid.
The interpretation of follicular cell atypia is hindered by sample preparation artifact.
Moderately or markedly cellular sample is composed of a virtually exclusive population of Hürthle cells, yet the clinical setting suggests a benign Hürthle cell nodule.

Minor population of follicular cells show nuclear enlargement, often accompanied by prominent nucleoli,
Focal features suggestive of papillary carcinoma, including nuclear grooves, enlarged nuclei with pale chromatin, and alterations in nuclear contour and shape in an otherwise predominantly benignappearing sample.
Cyst-lining cells that may appear atypical owing to the presence of nuclear grooves, prominent nucleoli, elongated nuclei and cytoplasm, and/ or intranuclear cytoplasmic inclusions in an otherwise predominantly benign appearing sample.

Atypical lymphoid infiltrate (in which a repeated aspirate for flow cytometry is desirable), but the degree of atypia is insufficient for the general category "suspicious for malignancy."
Not otherwise categorized 
Most recently non-invasive follicular thyroid neoplasm with papillary-like nuclear features (NIFTP) has been added to the list of the pathological diagnoses of thyroid nodules to avoid cancer terminology. NIFTP is not a benign lesion but it is also not an overt cancer since it carries an extremely low malignant potential, analogous to the "in situ" cancer. Therefore, diagnostic lobectomy would be adequate for diagnosis and treatment of NIFTP lesion without the need of total or completion thyroidectomy, radioactive iodine ablation, or intensive monitoring [4].

AUS/FLUS are classified as one of the intermediate cytologies and is obtained in $3-10 \%$ of thyroid FNA [5,6] (Table 1). Although AUS/FLUS are found in a minority of thyroid FNA it has created a diagnostic dilemma given its estimated 5-15\% risk of malignancy which can be worrisome to patients [3].

When presented with a diagnosis of AUS/FLUS the next step in management usually involves continued surveillance versus an invasive procedure. Therefore this usually leads to a repeat FNA, Core needle biopsy \pm flow cytometry, or diagnostic surgery which can lead to further patient morbidity. Experience with historical/ physical examination features suggestive of malignancy and the use of noninvasive techniques has contributed to improvements in the safety and cost-effectiveness of management of patients with thyroid nodules in general [7].

\section{Clinical Practice Guidelines for atypia of} undetermined significance or follicular lesion of undetermined significance (AUS or FLUS)

The most recent ATA guidelines 2015 recommends that after consideration of worrisome clinical and sonographic features, investigations such as repeat FNA or molecular testing may be used to supplement malignancy risk assessment [2]. The AACE guidelines 2016 recommends consideration of conservative management or repeat FNA for further cytologic assessment but does not recommend either in favor or against the determination of molecular markers for routine use in this category [8].

Determination of course of action after initial FNA shows AUS/FLUS

\section{Clinical features}

Although the history and physical examination cannot accurately predict malignancy, the acquisition of this information is vital to deciding on the course of action. Pertinent personal history includes neck area irradiation. Long-term survivors of childhood cancers who received radiotherapy to the head, neck or upper thorax are known to have not only an increased risk of thyroid nodules but are also at increased risk of developing thyroid cancer $[9,10]$. However, further evaluation should be similar to the standard of care of individuals with a thyroid nodule in the general population [11].

Well-differentiated thyroid cancer accounts for 95\% of thyroid malignancies, and $5 \%$ of these patients will have familial disease $[11,12]$. Therefore, family history of a first degree relative with familial thyroid cancer or thyroid cancer syndrome for example PTEN hamartoma tumor syndrome [Cowden's disease], familial adenomatous polyposis, Carney complex, Werner syndrome/progeria, or multiple endocrine neoplasia (MEN) type 2 should be obtained. Physical examination findings which may lead to suspicion of malignancy includes a rapid change in size of the nodule, a nodule that is hard on palpation or fixed to surrounding tissue and abnormal cervical lymphadenopathy.

\section{Laboratory}

For nodules that have returned with the categorization of AUS/FLUS, it is beneficial to review both thyrotropin testing and ultrasound of thyroid gland and lateral neck. It is well established that a subnormal TSH would warrant not a repeat FNA but instead warrant a radionuclide thyroid scan to exclude a hyper functioning, i.e. "hot" nodule because hyper functioning nodules are rarely malignant. A hot nodule will show hyperplastic follicular cells with nuclear enlargement, often accompanied by prominent nucleoli on cytology which makes the cells look atypical. A serum TSH in the normal or higher range is however associated with an increased risk of malignancy in a thyroid nodule $[2,13]$.

\section{Ultrasound}

Comparison of the 2016 AACE, 2015 ATA, and 2014 BTA thyroid nodule ultrasound classification systems reveals the following ultrasound features that are associated with an increased risk of malignancy found in all three classification systems include nodule height greater than its width, hypoechogenecity, solid nodule structure, the presence of micro calcifications or disruptive rim calcifications, and irregular margins (which can be defined as infitrative, microlobulated, or spiculated). The AACE and BTA also include pathologic lymphadenopathy as a feature of malignancy. Whereas the AACE and ATA include extra thyroidal growth and invasion as an additional risk category $[2,8,14,15]$. The combination of two more features increases the specificity for malignancy but has low ultrasound sensitivity for cancer [8].

Ultrasonographic features that invoke intermediate or equivocal suspicion for malignancy include indeterminate hyperechoic spots, slightly hypoechoic or homogenous nodules, intranodular or mixed/central vascularity, and absent halo sign, that is, periphery of nodule is surrounded by echo poor tissue $[2,8,14,15]$. Finally, ultrasonographic features that suggest low risk or benign nature include nodules with halos, isoechoic, spongiform, mildly hyperechoic nodules, or purely cystic nodules. $[2,8,15]$.

\section{Molecular markers}

The review article by Lathief et al. [16] highlights the ATA 2015 recommendation for molecular testing (strong recommendation, low quality evidence) to occur after counseling patients on benefits and limitations of testing and 
the AACE 2016 recommendation that molecular testing to complement cytologic evaluation (grade A). Testing for detection of BRAF, RET/PTC, PAX8/PPRG, and RAS mutations are also recommended (grade $\mathrm{B}$ ). Overall, thyroid molecular testing can be a useful tool when combined with clinical and ultrasound risk Table 2: Overview of 4 commercially available genetic tests for atypical

\begin{tabular}{|c|c|c|c|c|}
\hline Test & Afirma & $\begin{array}{l}\text { ThyroSeqverion } 2 \text { Next } \\
\text { Generation Sequencing }\end{array}$ & ThyGenX/ ThyraMIR & Rosetta GXReveal \\
\hline Company & Veracyte & $\begin{array}{l}\text { University of Pittsburgh } \\
\text { Medical Center through } \\
\text { CBL Path }\end{array}$ & Interspace Diagnostics & Rosetta Genomics \\
\hline Methods & $\begin{array}{l}\text { Based on mRNA (gene } \\
\text { expression); classified as } \\
\text { benign or malignant }\end{array}$ & $\begin{array}{c}\text { Next-generation } \\
\text { sequencing which detects } \\
\text { 14 gene mutations (AKT1, } \\
\text { BRAF, CTNNB1,GNAS, } \\
\text { HRAS, KRAS, } \\
\text { NRAS,PIK3CA, PTEN, RET, } \\
\text { TP53, SHR,TERT, and } \\
\text { EIF1AX and > 42 gene } \\
\text { rearrangements (RET-PTC, } \\
\text { PAX-8/PPARG etc) }\end{array}$ & $\begin{array}{l}\text { ThyGen X: Uses PCR for } \\
\text { detection of } 7 \text { common } \\
\text { gene mutations (BRAF, } \\
\text { RAS, NRAS, and KRAS) } \\
\text { and rearrangements } \\
\text { (RET-PTC1, RET-PTC3, and } \\
\text { PAX8-PPARG) first with } \\
\text { sequence-specific probes. } \\
\text { If initial mutation panel } \\
\text { is negative then further } \\
\text { testing for 10-gene micro } \\
\text { RNA classifier (ThyraMIR: } \\
\text { expression analysis) will } \\
\text { be done. }\end{array}$ & $\begin{array}{c}\text { Micro RNA-based } \\
\text { diagnostic assay. First } \\
\text { thyroid test that works } \\
\text { on stained FNA smears } \\
\text { containing at least } 60 \text { cells } \\
\text { for analysis }\end{array}$ \\
\hline Strengths & $\begin{array}{c}\text { High NPV: } \\
\text { AUS/FLUS- 95\% } \\
\text { “ Rule Out"Test } \\
\text { Identifies MTC with MTC } \\
\text { gene classifier }\end{array}$ & $\begin{array}{c}\text { High PPV 68-72\% } \\
\text { "Rule in test" } \\
\text { High NPV } 96 \% \\
\text { “Rule Out" assay } \\
\text { Risk stratification } \\
\text { based on mutation and } \\
\text { prognostic value }\end{array}$ & $\begin{array}{l}\text { High NPV } 94 \% \\
\text { High PPV } 74 \%\end{array}$ & $\begin{array}{l}\text { High NPV 91\% } \\
\text { Rule out test }\end{array}$ \\
\hline Limitations & $\begin{array}{c}\text { Low PPV } \\
\text { AUS/FLUS- 38\% } \\
\text { High false positive results }\end{array}$ & $\begin{array}{l}\text { Newer assay with limited } \\
\text { experience }\end{array}$ & $\begin{array}{c}\text { New assay with limited } \\
\text { experience }\end{array}$ & Low PPV 59\% \\
\hline
\end{tabular}

*Abbreviations: AUS: Atypia of Undetermined Significance; FLUS: Follicular Lesion of Undetermined Significance; MTC: Medullary Thyroid Cancer; NPV: Negative Predictive Value; PPV: Positive Predictive Value

\section{Conclusion}

Management options for an initial atypical thyroid nodule biopsy like AUS/FLUS include observation, repeat FNA, diagnostic lobectomy or thyroidectomy. Laboratory, clinical and ultrasound findings provide valuable information that can be incorporated into the decision making process. Molecular testing which are described briefly in this review should be used as an adjunct to these findings and may serve to limit the need for more invasive procedures. Thus, when considering management for patients with AUS/FLUS, it is important take into consideration laboratory, clinical, ultrasound findings, and molecular markers to help aid in decision making.

\section{Conflict of Interest and Funding}

The authors have not received any funding or benefits from industry or elsewhere to conduct this study. assessment of indeterminate thyroid cytology. (Table 2) outlines four commercially available genetic tests for molecular testing, adapted from our review article on advances and practical use of the molecular markers for thyroid cancer [16]. 
in different diagnostic categories of the Bethesda system for reporting thyroid cytopathology: An institutional experience. Biomed J38(6): 517-522.

7. Burch HB (1995) Evaluation and management of the solid thyroid nodule. Endocrinol Metab Clin North Am 24(4): 663-710.

8. Gharib H, Papini E, Garber JR, Duick DS, Harrell RM, et al. (2016) AMERICAN ASSOCIATION OF CLINICAL ENDOCRINOLOGISTS, AMERICAN COLLEGE OF ENDOCRINOLOGY, AND ASSOCIAZIONE MEDICI ENDOCRINOLOGI MEDICAL GUIDELINES FOR CLINICAL PRACTICE FOR THE DIAGNOSIS AND MANAGEMENT OF THYROID NODULES--2016 UPDATE. Endocr Pract 22(5): 622-639.

9. Oeffinger KC, Baxi SS, Novetsky Friedman D, Moskowitz CS (2013) Solid tumor second primary neoplasms: who is at risk, what can we do? Semin Oncol 40(6): 676-689.

10. Sigurdson AJ, Ronckers CM, Mertens AC, Stovall M, Smith SA, et al. (2005) Primary thyroid cancer after a first tumour in childhood (the Childhood Cancer Survivor Study): a nested case-control study. Lancet 365(9476): 2014-2023.

11. Richards ML (2010) Familial syndromes associated with thyroid cancer in the era of personalized medicine. Thyroid 20(7): 707-713.

12. Richards ML (2009) Thyroid cancer genetics: multiple endocrine neoplasia type 2, non-medullary familial thyroid cancer, and familial syndromes associated with thyroid cancer. Surg Oncol Clin N Am 18(1): 39-52.

13. Boelaert K, Horacek J, Holder RL, Watkinson JC, Sheppard MC, et al. (2006) Serum thyrotropin concentration as a novel predictor of malignancy in thyroid nodules investigated by fine-needle aspiration. J Clin Endocrinol Metab 91(11): 4295-4301.

14.Wong KT, Ahuja AT (2005) Ultrasound of thyroid cancer. Cancer Imaging 5(1): 157-166.

15. Petros Perros, Kristien Boelaert, Steve Colley, Graham R Williams (2014) British Thyroid Association Guidelines for the Management of Thyroid Carcinoma. Clin Endocrinol 81(S1): 1-122.

16. Lathief S, Pothuloori A, Liu X, Chaidarun S (2016) Advances and practical use of the molecular markers for thyroid cancer. Adv Cell Mol Otolaryngol 4: 33948.

Your next submission with Juniper Publishers will reach you the below assets

- Quality Editorial service

- Swift Peer Review

- Reprints availability

- E-prints Service

- Manuscript Podcast for convenient understanding

- Global attainment for your research

- Manuscript accessibility in different formats

( Pdf, E-pub, Full Text, Audio)

- Unceasing customer service

Track the below URL for one-step submission https://juniperpublishers.com/online-submission.php 